\title{
Non-Secretory Plasma Cell Myeloma
}

National Cancer Institute

\section{Source}

National Cancer Institute. Non-Secretory Plasma Cell Myeloma. NCI Thesaurus. Code C4734.

A rare type of multiple myeloma in which the plasma cells synthesize but do not secrete immunog lobulins. As a result, none of the immunoglobulins appear out of the normal range. The symptoms are generally the same with those of immunoglobulin-secreting myeloma; however, the incidence of renal insufficiency is lower in non-secretory myeloma. The diagnosis can be missed because of the absence of monoclonal immunog lobulin in the serum or urine. 